\title{
Dose-response relationship of stereotactic body radiotherapy for ultracentral tumor and comparison of efficacy with central tumor: a meta-analysis
}

\author{
Chai Hong Rim ${ }^{1 \#}$, In-Soo Shin ${ }^{2 \#}$, Won Sup Yoon ${ }^{1}$, Sunmin Park ${ }^{1}$ \\ ${ }^{1}$ Department of Radiation Oncology, Korea University Ansan Hospital, Ansan, Republic of Korea; ${ }^{2}$ Graduated School of Education, Dongguk \\ University, Seoul, Republic of Korea \\ Contributions: (I) Conception and design: CH Rim; (II) Administrative support: CH Rim; (III) Provision of study materials or patients: CH Rim; (IV) \\ Collection and assembly of data: CH Rim, IS Shin; (V) Data analysis and interpretation: All authors; (VI) Manuscript writing: All authors; (VII) Final \\ approval of manuscript: All authors. \\ \#These authors contributed equally to this work. \\ Correspondence to: Chai Hong Rim. Department of Radiation Oncology, Ansan Hospital, Korea University, 123 Jeokgeum-ro, Danwon-gu, Ansan, \\ Gyeonggi-do, 15355, Republic of Korea. Email: crusion3@naver.com.
}

Background: Ultracentral (UC) tumors, a subset of central lung tumors defined as those that abut the proximal bronchial tree (PBT), have been contraindicated for stereotactic body radiotherapy (SBRT). The present meta-analysis evaluated the efficacy of SBRT for UC and central tumors, and dose-response for local control (LC) of UC tumors.

Methods: Databases including MEDLINE and EMBASE were searched up to March, 2020, to identify studies regarding SBRT for UC and/or central tumors. The primary endpoints were LC and overall survival (OS), while secondary endpoints were grade $\geq 3$ and 5 complications.

Results: Fourteen studies including 892 patients were included. In the UC and central tumor groups, the 1-year OS rates were $82.2 \%$ and $85.4 \%(\mathrm{P}=0.556)$, respectively, and the 2 -year OS rates were $66.4 \%$ and $71.9 \%(\mathrm{P}=0.522)$, respectively. The 1- and 2-year LC rates in the UC and central tumor groups were $93.9 \%$ and $97.8 \%(\mathrm{P}=0.023)$ and $90.4 \%$ and $93.7 \%(\mathrm{P}=0.459)$, respectively. The pooled grade $\geq 3$ complication rates in the $\mathrm{UC}$ and central tumor groups were $9.0 \%$ and $4.4 \%(\mathrm{P}=0.06)$, while the corresponding grade 5 complication rates were $5.7 \%$ and $2.1 \%(\mathrm{P}=0.087)$. The dose-response for LC was shown in the metaregression $(\mathrm{P}<0.0001)$, and 1 -year $\mathrm{LC}$ rates were significantly different $(94.4 \%$ vs. $59.3 \%, \mathrm{P}<0.001)$ with very low heterogeneities in both subgroups, with threshold of 85 Gy10. Of the 28 fatalities, 12 (42.8\%) were caused by hemorrhage or bronchial stenosis, and another $12(42.8 \%)$ by pneumonia or respiratory failure.

Conclusions: The oncologic outcomes of patients with UC and central tumors were comparable postSBRT. A dose of at least $\geq 85$ Gy10 is recommended for SBRT of UC tumors. Causes of complications should be further studied as UC tumors are more prone to serious toxicities.

Keywords: Lung cancer; central tumor; ultracentral (UC) tumor; stereotactic body radiotherapy (SBRT); stereotactic ablative body radiotherapy

Submitted Mar 26, 2020. Accepted for publication Jun 30, 2020.

doi: $10.21037 /$ tlcr-20-503

View this article at: http://dx.doi.org/10.21037/tlcr-20-503 


\section{Introduction}

Lung cancer has long been the primary cause of cancerrelated deaths (1), and surgical resection has been the standard curative modality for early-stage disease $(2,3)$, Although external beam radiotherapy (EBRT) had previously been applied for locally advanced or metastatic disease, precise tumor targeting using updated technologies namely, stereotactic body radiotherapy (SBRT), enable curative treatment. Unlike conventional EBRT, SBRT delivers a very high dose precisely to the target in a relatively short period, and recent randomized trials have shown that outcomes post-SBRT were comparable to those following surgery $(4,5)$.

The feasibility and efficacy of SBRT for treating peripheral tumors were previously demonstrated, but those for treating central tumors remain unclear. An early trial found that the risk of grade $\geq 3$ toxicity was 11 -fold higher when using SBRT to treat central tumors, defined as those within a $2 \mathrm{~cm}$ radius of the proximal bronchial tree (PBT), than treating peripheral tumors (6). However, central tumors are commonly inoperable or require more extensive surgery than do peripheral tumors; hence, many researchers have continued administering SBRT to central tumors using more protracted regimens. With the downside of having a moderate risk level of complications (the grade $\geq 3$ complication rate is $\sim 9 \%$ ), the oncologic outcomes of patients treated with SBRT for central tumors were comparable to those treated for peripheral tumors $(7,8)$.

While careful administration of SBRT to central tumors has been performed, an independent concept of "ultracentral" (UC) tumors was introduced; this generally refers to tumors that abut the PBT (9). When SBRT is applied to such tumors, the target volume must cover the $\mathrm{PBT}$, rendering its irradiation with the full treatment dose inevitable. Corradetti et al. (10). described a patient who developed fatal central airway necrosis owing to UC tumor irradiation and, therefore, warned of the risk of such a treatment. However, UC tumors are more intractable and have fewer curative options than do central tumors. In early studies, some investigators reported serious toxicity rates of over $20 \%(11,12)$, while other studies reported more favorable results $(4,13)$.

Several researchers eagerly reported their clinical experiences recently, and their data were more encouraging than in the past. A suitable SBRT dose information for UC tumors has been longed by clinicians. At the same time, whether UC tumors have different outcomes post-SBRT from central tumors is controversial (13-17). Hence, the present meta-analysis was performed to assess the doseresponse relationship and feasibility of SBRT for UC tumors and to compare outcomes between UC and central tumors.

We present the following article in accordance with the PRISMA reporting Guideline (available at http://dx. doi. org/10. 21037/tlcr-20-503).

\section{Methods}

The present meta-analysis and systematic review were performed to address the following clinical (PICO) questions: "(I) Does SBRT for UC tumors have feasibility and dose-response relationship? (II) Are UC tumors a distinct clinical subset of central tumors for purposes of considering SBRT application?" Databases including MEDLINE and EMBASE were searched for records available up to March 1, 2020. We used the following search terms: (ultracentral OR "ultra central" OR "ultra-central") and lung and ("radiation therapy" or "radiotherapy"). Reference lists from the searched articles were used to locate additional publications. No language or time restrictions were applied. Unpublished literature was considered if it fully satisfied the inclusion criteria.

\section{Inclusion criteria}

Eligible studies included in the present meta-analysis met all of the following criteria: (I) clinical trials; (II) inclusion of $\geq 5$ patients with UC tumors who underwent SBRT; (III) definition of UC tumor must include "abutting the PBT" (e.g., tumors described as " $<1 \mathrm{~cm}$ from the PBT" were not included, as they could encompass central tumors); (IV) SBRT was delivered at either $>4$ Gy per fraction or in $\leq 10$ fractions; (V) SBRT was not performed in re-irradiation setting and 5) at least one of the primary endpoints was reported. The primary endpoints were rates of local control (LC) and overall survival (OS), while secondary endpoints were of grade $\geq 3$ or grade 5 complications. Initial screening was performed using citations and titles to filter out duplicate studies, reviews, editorials, letters, and in vivo or in vitro studies. Abstracts were reviewed to exclude studies with irrelevant subjects or formats. Full-text reviews were then performed to identify studies that fulfilled all the inclusion criteria. Multiple studies from the same institutions were sorted using the following criteria-prioritized in numerical order: (I) studies with the largest number of 
patients with UC; (II) published articles were preferred over conference abstracts. We included multiple studies from the same institution if they had no overlapping patients or if the overlap was negligible. Screening for these inclusion criteria was performed by two independent researchers, and final inclusion was decided upon mutual consent.

\section{Data collection}

Data collection from the included studies was performed using a pre-designed standardized form to evaluate (I) background information including authors, affiliations, study type, and number of patients; (II) clinical information including $\mathrm{T}$ stage, proportion of squamous histology cases, target volume, proportion of metastasis or recurrence cases, SBRT dose, and definition of UC tumor; (III) outcomes of interest including LC, OS, and complication of grade $\geq 3$. LC and OS rates were estimated from descriptive graphs, considering follow-up periods, in the absence of numeral data. The prescribed SBRT doses were converted to the biologically equivalent dose (BED) using an $\alpha / \beta$ ratio of 10 and equivalent dose in 2 Gy fractions (EQD2) using $\alpha / \beta$ ratios of 3 and 10 . An $\alpha / \beta$ ratio of 10 represented aggressive biologic behavior in the early responding tissues (i.e., the tumors), while an $\alpha / \beta$ ratio of 3 represented that in late-responding tissues and was commonly used to estimate complication risks (18). The data collection process was performed by two independent researchers, and disagreements were resolved by conducting an additional literature review and mutual discussion.

\section{Quality assessment}

As most of the included studies were retrospective, the Newcastle-Ottawa scale (19) was used for quality assessment. Studies with scores of 7-9 and 4-6 were considered to be of high and medium qualities, respectively.

\section{Statistical analysis}

Pooled analyses were performed for all primary and secondary endpoints. The selection of the effects model depended on the nature of the included studies and their data, rather than on the calculated heterogeneity (20). A random-effects model was used considering the inevitable heterogeneity of the patients' characteristics and treatment details (21). Heterogeneity among the studies was assessed using Cochran Q test and $\mathrm{I}^{2}$ statistics; $(22,23)$. Significant heterogeneity was considered present when $\mathrm{P}<0.1$ and $\mathrm{I}^{2} \geq 50 \% ; \mathrm{I}^{2}$ values of $25 \%, 50 \%$, and $75 \%$ corresponded to low, moderate, and high degrees of heterogeneity, respectively. Pooled analyses of 1- and 2-year LC and OS rates were performed for controlled studies, whereas only analyses of 1-year LC and OS rates were performed for all studies because the follow-up durations were short in single-arm UC case series. Subgroup comparisons were performed using $\mathrm{Q}$ tests on the basis of analysis of variance, and $\mathrm{P}$ values $<0.05$ indicated significant differences among the subgroups. Meta-regression was performed to quantitatively assess the relationship between the endpoints and $\mathrm{BED}_{10 \mathrm{G} y}$, and $\mathrm{P}$ values $<0.05$ represented significant correlations. Publication biases were evaluated via the visual inspection of funnel plots, quantitative results of the Egger's test, and analyzing Rosenthal's fail-safe number $(24,25)$. If funnel plot inspection showed asymmetric distributions and the 2 -tailed $\mathrm{P}$ value of the Egger's test was $<0.1$, then the fail-safe number was calculated; if the possibility arose that studies similar to that number may have been missed, Duval and Tweedie's trim and fill method (26) was used to determine the corrected relevant values. All statistical analyses were conducted using the Comprehensive MetaAnalysis software version 3 (Biostat, Inc., Englewood, NJ).

\section{Results}

Among the 72 studies that were initially searched, 14 studies including 892 patients (411 and 481 with UC and central tumors, respectively), were finally included (9,11-17,27-32). The study inclusion process is described in Figure S1. Eight of the studies were controlled trials that included patients with both UC and other central tumors, whereas six were single-arm observational studies of patients with UC. Two studies from Georgetown University were included in the final list $(28,29)$, as the authors unanimously agreed that the number of overlapping patients was small enough not to yield a significant bias whereas including the data would enrich the pooled analyses. We also included our older data that were reported in a previous publication and subsequently updated $(30,33)$. All the included studies were described in full-text articles. Six single-arm observational studies $(11,27-30,32)$ were categorized as having medium quality according to the Newcastle-Ottawa scale, and 8 controlled studies $(9,13-17)$ were considered high-quality.

The proportions of T1 tumors ranged from $2 \%$ to $76 \%$ with a median of $51.8 \%$. The median PTV ranged from 23.2 to $111.3 \mathrm{~cm}^{3}$, with a median of $68.5 \mathrm{~cm}^{3}$. The median 
prescribed dose ranged from 59.5 to $132 \mathrm{BED}_{\mathrm{Gy} 10}$, with a median of $100 \mathrm{BED}_{\mathrm{Gy} 10}$. Basic information about the included studies is summarized in Table 1, while clinical information is shown in Table 2.

\section{Comparison of UC and other central tumors}

In pooled analyses of the controlled studies, the 1-year LC rates were $93.9 \%$ (95\% CI: 95.6-98.9\%) and 97.8\% (95\% CI: 95.6-98.9\%) in the UC and central tumor groups, respectively $(\mathrm{P}=0.023)$, while the corresponding 2 -year LC rates were $90.4 \%$ (95\% CI: $77.8-96.2 \%)$ and $93.7 \%$ (95\% CI: $88.3-96.7 \%)$, respectively $(\mathrm{P}=0.459)$. Moreover, the corresponding 1-year OS rates were $82.2 \%$ (95\% CI: $71.7-$ $89.7 \%$ ) and $85.4 \%$ (95\% CI: 78.9-90.1\%), respectively $(\mathrm{P}=0.556)$, while the 2 -year OS rates were $66.4 \%(95 \%$ CI: $51.4-78.7 \%$ ) and $71.9 \%$ (95\% CI: $61.0-80.8 \%$ ), respectively $(\mathrm{P}=0.522)$. The pooled grade $\geq 3$ complication rates in the UC and central tumor groups were $9.0 \%(95 \%$ CI: $5.0-15.9 \%)$ vs. $4.4 \%$ (95\% CI: $2.8-6.9 \%)(\mathrm{P}=0.06)$, while the grade 5 complication rates were $5.7 \%$ (95\% CI: 2.6-11.9\%) vs. $2.3 \%$ (95\% CI: $1.1-4.6 \%)(\mathrm{P}=0.087)$. The results of the pooled analyses are summarized in Table 3 and are also shown as forest plots in Figure 1.

\section{Pooled analyses among all UC cohort}

In a pooled analyses of all UC cohorts from controlled and single-arm studies, the 1-year LC and OS rates were $90.2 \%$ (95\% CI: 80.1-95.4\%) and 77.6\% (95\% CI: 69.5-84.0\%), respectively; moreover, grades $\geq 3$ and 5 complication rates were $10.4 \%$ (95\% CI: $5.9-17.7 \%$ ) and $6.1 \%$ (95\% CI: $3.3-11.0 \%)$, respectively. Subgroup comparisons were performed according to the percent of patients in a study with recurrence or metastases, and median PTV volume. On subgroup comparisons, the 1-year LC rates were 94.1\% (95\% CI: $89.2-96.8 \%$ ) and $83.0 \%$ (95\% CI: $65.5-92.6 \%)$ in the subgroups representing recurrence or metastases incidences of $<50 \%$ and $\geq 50 \%$, respectively $(\mathrm{P}=0.045)$. The pooled 1 -year OS rates were $87.0 \%$ (95\% CI: 79.0-92.3\%) and $69.9 \%$ (95\% CI: $61.0-77.4 \%$ ) in the subgroups representing median PTVs of $\leq 78$ and $>78 \mathrm{~cm}^{3}$, respectively $(\mathrm{P}=0.003)$. Above results are summarized in Table 4.

\section{Dose-response for LC among all UC cohort (meta- regression analyses)}

The median $\mathrm{BED}_{10 \mathrm{~Gy}}$ of the studies was significantly correlated with the 1 -year LC rate $(\mathrm{P}<0.0001$, Figure $2 A)$. With the threshold of $85 \mathrm{~Gy}_{10}$, commonly prescribed as 55 Gy in 10 fractions or 45 Gy in 5 fractions, 1-year LC rates were significantly different $(94.4 \%$ vs. $59.3 \%, \mathrm{P}<0.001)$ with very low heterogeneities in both subgroups $\left(\mathrm{I}^{2}=\sim 0 \%\right.$ in both); the result is shown in Figure $2 B$ in detail. Metaregression results were not statistically significant between the median $\mathrm{BED}_{10 \mathrm{~Gy}}$ and 1-year OS, grade $\geq 3$ complications, and grade 5 complications. The results of meta-regression analyses are shown in Table 4. Forest plots and scatterplots of meta-regression were shown in Figure $S 2$.

\section{Qualitative analysis of fatal complications}

As fatal complications are the most important concern when applying SBRT for UC tumors, we qualitatively analyzed the reported toxicities in addition to the pooled analyses. Data regarding fatal complications were available for all the included studies involving 892 patients (411 and 481 with UC and central tumors); fatal complications were reported in 28 patients. Among them, 24 had UC tumors while 4 had other central tumors. The fatal complications among patients with UC tumors were hemorrhage (9, $37.5 \%)$, pneumonia or respiratory failure $(9,37.5 \%)$, bronchial stenosis or fistula $(3,12.5 \%)$, and cardiac toxicity $(3,12.5 \%)$. Fatal complications among patients with central tumors included pneumonitis $(3,75 \%)$ and myocardial infarction $(1,25 \%)$. The reported complication rates and their suggested risk factors are shown in Table 5 .

\section{Publication bias assessment}

Egger's test showed that possible publication bias was present for the 1 -year $\mathrm{LC}$ rate $(\mathrm{P}<0.001), 2$-year $\mathrm{LC}$ rate $(\mathrm{P}=0.005), 1$-year $\mathrm{OS}$ rate $(\mathrm{P}=0.051)$, grade $\geq 3$ complication rate $(\mathrm{P}=0.003)$, and grade 5 complication rate $(\mathrm{P}<0.001)$. The fail-safe numbers (e.g., the numbers of unpublished or unfound studies enough to statistically nullify observed effects) to prevent publication bias were $889,719,877$, 1,348 , and 1,294 , respectively. Since it is unreasonable to assume that studies with these numbers were missing from our literature search, the originally observed effect sizes rather than adjusted values were shown as results.

\section{Discussion}

Tumors abutting the PBT are generally either inoperable or require extensive surgery such as pneumonectomy 


\begin{tabular}{|c|c|c|c|c|c|c|c|c|c|c|c|c|}
\hline First author & $\begin{array}{l}\text { Source of } \\
\text { information }\end{array}$ & Affiliation & $\begin{array}{l}\text { Study } \\
\text { type }\end{array}$ & $\begin{array}{l}\text { NOS } \\
\text { score }\end{array}$ & $\begin{array}{l}\text { Patients } \\
\text { (n) }\end{array}$ & Age $[y]$ & T1; T2; T3 (\%) & $\begin{array}{l}\text { SQCC } \\
(\%)\end{array}$ & ECOG PS score & Median PTV (range) (cm3) & Metastasis or recurrence (\%) & UC definition \\
\hline \multicolumn{13}{|c|}{ Studies of both $\mathrm{UC}$ and $\mathrm{C}$ tumors } \\
\hline \multirow[t]{2}{*}{ Raman } & $\begin{array}{l}\text { Clin Lung Cancer, } \\
2018\end{array}$ & $\begin{array}{l}\text { Princess Margaret } \\
\text { Cancer Center, Canada }\end{array}$ & $\mathrm{R}$ & 9 & UC: 21 & 74 [44-89] & $55 ; 45 ; 0$ & 52.6 & $0-1(90.5 \%)$ & $68.5(20.1-238.3)$ & 0 & $\begin{array}{l}\text { PTV directly abuts/overlaps the PBT, trachea, } \\
\text { esophagus, pulmonary vein/artery }\end{array}$ \\
\hline & & & & & C: 161 & 76 [51-91] & $66.9 ; 31.3 ; 1.9$ & 21.5 & $0-1(78.9 \%)$ & $42.4(9.7-246.3)$ & 0 & \\
\hline Comparison (P) & & & & & & 0.77 & 0.41 & 0.01 & 0.05 & 0.004 & n/a & \\
\hline \multirow[t]{2}{*}{ Lenglet } & $\begin{array}{l}\text { Radiother Oncol, } \\
2019\end{array}$ & $\begin{array}{l}\text { l'Université de } \\
\text { Montréal, Canada }\end{array}$ & $\mathrm{R}$ & 9 & UC: 77 & 75 [51-94] & $48 ; 27 ; 25$ & 35 & $\begin{array}{l}\text { Median KPS } 90 \\
\quad(50-100)\end{array}$ & $31.1(6.6-274.3)$ & 0 & $\begin{array}{l}\text { PVT overlaps PBT, trachea, great vessels, } \\
\text { pericardium }\end{array}$ \\
\hline & & & & & C: 60 & 75 [56-92] & $65 ; 20 ; 15$ & 23 & $\begin{array}{l}\text { Median KPS } 90 \\
\quad(50-100)\end{array}$ & $23.2(6.5-111.2)$ & 0 & \\
\hline Comparison $(\mathrm{P})$ & & & & & & n/a & $n / a$ & n/a & n/a & n/a & n/a & \\
\hline \multirow[t]{2}{*}{ Meng } & Cancer Sci, 2019 & $\begin{array}{l}\text { Tianjin medical university, } \\
\text { China }\end{array}$ & $\mathrm{R}$ & 9 & UC: 37 & 71 [51-85] & 48.6; $51.1(\mathrm{T1} 1,2)$ & 40.6 & & $55.0(9.9-264.5)$ & 0 & Abutment of PBT \\
\hline & & & & & C: 43 & $71[51-83]$ & $44.2 ; 48.8(\mathrm{~T} 1,2)$ & 48.8 & & $49.2(2.8-159.7)$ & 0 & \\
\hline Comparison (P) & & & & & & 0.99 & 0.16 & 0.15 & & 0.5 & n/a & \\
\hline \multirow[t]{2}{*}{ Chang } & $\begin{array}{l}\text { Radiother Oncol, } \\
\quad 2018\end{array}$ & $\begin{array}{l}\text { Sunnybrook Odette } \\
\text { Cancer Center, Canada }\end{array}$ & $\mathrm{R}$ & 7 & UC: 46 & $\begin{array}{c}72 \\
{[63-80, \text { IQR }]}\end{array}$ & & & & $\begin{array}{l}78.9 \\
(45.7-136, \text { IQR) }\end{array}$ & $\begin{array}{l}73.9 \text { (mostly oligomets or } \\
\text { oligoprogression) }\end{array}$ & ITV directly abutted the proximal bronchial tree \\
\hline & & & & & C: 61 & $\begin{array}{c}75 \\
{[67-83, \text { IQR }]}\end{array}$ & & & & $\begin{array}{l}55.2 \\
(42.5-107, \text { IQR })\end{array}$ & 41 (mostly oligomets or oligoprogression) & \\
\hline Comparison (P) & & & & & & 0.16 & & 0.01 & & 0.26 & 0.0079 & \\
\hline & & & & & C: 90 & 79 [52-95] & 76; $24(\mathrm{~T} 1,2)$ & 77 & $\mathrm{KPS} \geq 80$ in $70 \%$ & $\leq 3 \mathrm{~cm}$ in $74 \%$ & & \\
\hline Comparison (P) & & & & & & 0.13 & NS & 0.022 & NS & NS & $n / a$ & \\
\hline \multirow[t]{2}{*}{ Chaudhuri } & $\begin{array}{l}\text { Lung Cancer, } \\
\qquad 2015\end{array}$ & Stanford University, US & $\mathrm{R}$ & 8 & UC: 7 & $74[30-90]$ & $62.9 ; 33.3 ; 3.7$ & 33.3 & & $44.7(14.2-224)$ & not reported & $\begin{array}{l}\text { GTV abuts proximal branch or trachea } \\
\text { (excluding GTV abuts esophagus) }\end{array}$ \\
\hline & & & & & C: 21 & & & & & & & \\
\hline Comparison (P) & & & & & & n/a & n/a & n/a & n/a & $n / a$ & $n / a$ & \\
\hline \multirow[t]{2}{*}{ Nguyen } & $\begin{array}{l}\text { Pract Radiat } \\
\text { Oncol, } 2019\end{array}$ & $\begin{array}{c}\text { University of } \\
\text { California Davis, US }\end{array}$ & $R$ & 8 & UC: 14 & $66[41-87]$ & & & & & 7.1 & PVT overlap PBT or esophagus \\
\hline & & & & & C: 39 & 73 [31-92] & & & & & 30.7 & \\
\hline Comparison (P) & & & & & & n/a & $n / a$ & n/a & $\mathrm{n} / \mathrm{a}$ & $n / a$ & $n / a$ & \\
\hline \multirow[t]{2}{*}{ Cooke } & $\begin{array}{l}\text { Tech Innov Patient } \\
\text { Support Radiat } \\
\text { Oncol, } 2020\end{array}$ & $\begin{array}{l}\text { University of } \\
\text { Oxford, UK }\end{array}$ & $\mathrm{R}$ & 7 & UC: 22 & 71 [38-89] & & & $\begin{array}{l}0(48.1 \%) ; \\
1(51.9 \%)\end{array}$ & $73.6(64.3-100)$ & 100 (all oligometastasis) & GTV directly abut PBT \\
\hline & & & & & C: 6 & & & & & $100.4(96.1-103.2)$ & & \\
\hline Comparison (P) & & & & & & $n / a$ & $n / a$ & $n / a$ & $n / a$ & $n / a$ & $n / a$ & \\
\hline
\end{tabular}




\begin{tabular}{|c|c|c|c|c|c|c|c|c|c|c|c|c|}
\hline First author & $\begin{array}{l}\text { Source of } \\
\text { information }\end{array}$ & Affiliation & $\begin{array}{l}\text { Study } \\
\text { type }\end{array}$ & $\begin{array}{l}\text { NOS } \\
\text { score }\end{array}$ & $\begin{array}{l}\text { Patients } \\
\text { (n) }\end{array}$ & Age $[y]$ & T1; T2; T3 (\%) & $\begin{array}{l}\mathrm{SQCC} \\
(\%)\end{array}$ & ECOG PS score & Median PTV (range) (cm3) & Metastasis or recurrence (\%) & UC definition \\
\hline \multicolumn{13}{|c|}{ Single-arm studies } \\
\hline Tekatli & $\begin{array}{l}J \text { Thorac Oncol, } \\
2016\end{array}$ & $\begin{array}{l}\text { VU University } \\
\text { Medical Center, Netherland }\end{array}$ & $\mathrm{R}$ & 6 & UC: 4 & $\begin{array}{c}77.5 \\
{[57.7-90.8]}\end{array}$ & $\begin{array}{l}\text { 8; 36; } 38 \text { (remainders are } \\
\text { described as 'recurrent') }\end{array}$ & 49 & WHO 0-1 (51\%) & $104.5(17.7-508.5)$ & 17 & PTV overlaps trachea of main bronchi \\
\hline Cong & $\begin{array}{l}\text { Thorac Cancer, } \\
\qquad 2019\end{array}$ & $\begin{array}{l}\text { Chinese PLA } \\
\text { General Hospital, China }\end{array}$ & $\mathrm{R}$ & 4 & UC: 51 & 63 [35-82] & 2; 11.8; 31.4; $54.9(\mathrm{~T} 4)$ & 56.9 & $0-1(96.1 \%)$ & $111.3(9.8-688.9)$ & 60.8 & GTV overlapping trachea or PBT \\
\hline Lischalk & $\begin{array}{l}\text { Radiat Oncol, } \\
2016\end{array}$ & $\begin{array}{l}\text { Georgetown University, } \\
\text { US (2008-2011) }\end{array}$ & $\mathrm{R}$ & 5 & UC: 20 & 66 [24-82] & & 20 & $0-1(100 \%)$ & Mean $111.3(22.6-300)$ & 100 (Controlled metastases: 65) & $\begin{array}{l}\text { "High-risk," with abutment or invasion to } \\
\text { mainstem bronchus }\end{array}$ \\
\hline Unger & $\begin{array}{l}\text { J Hematol Oncol, } \\
2010\end{array}$ & $\begin{array}{l}\text { Georgetown University, } \\
\text { US (2005-2009) }\end{array}$ & $\mathrm{R}$ & 4 & UC: 20 & $63.5[13-82]$ & & & $0-1(75 \%)$ & GTV: $73(23-324)$ & 85 (Lung primary, 41) & $\begin{array}{l}\text { "High-risk," with abutment or invasion to } \\
\text { mainstem bronchus }\end{array}$ \\
\hline Yang & $\begin{array}{l}\text { Thorac Cancer, } \\
2020\end{array}$ & Peking University & $R$ & 5 & UC: 21 & 66 [52-81] & $27.3 ; 31.8 ; 9.5 ; 28.6$ & 38.1 & & $36.5(16.4-133.1)$ & 52.40 & $\begin{array}{l}\text { PTV abut PBT, heart, great vessel, but not } \\
\text { esophagus }\end{array}$ \\
\hline Park & $\begin{array}{l}\text { Int J Radiat Biol, } \\
2019\end{array}$ & Korea University, Korea & $\mathrm{R}$ & 4 & UC: 10 & $66[51-75]$ & & 50 & $0-1$ & Mean $83.7(17.1-144.3)$ & 60 & GTV abutting PBT \\
\hline
\end{tabular}

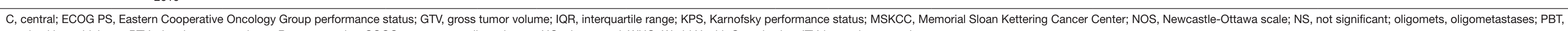
proximal bronchial tree; PTV, planning target volume; R, retrospective; SQCC, squamous cell carcinoma; UC, ultracentral; WHO, World Health Organization; ITV, internal target volume. 


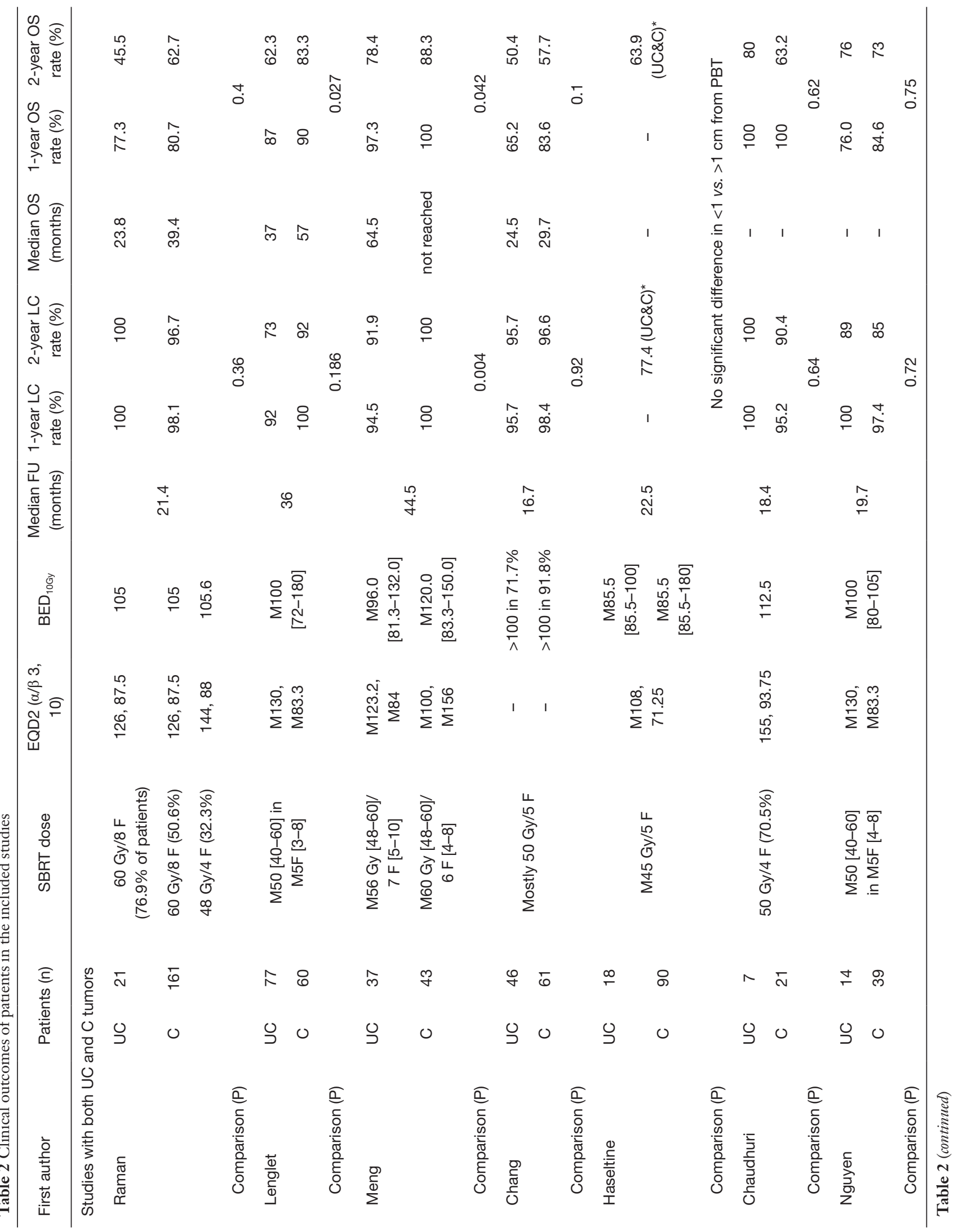




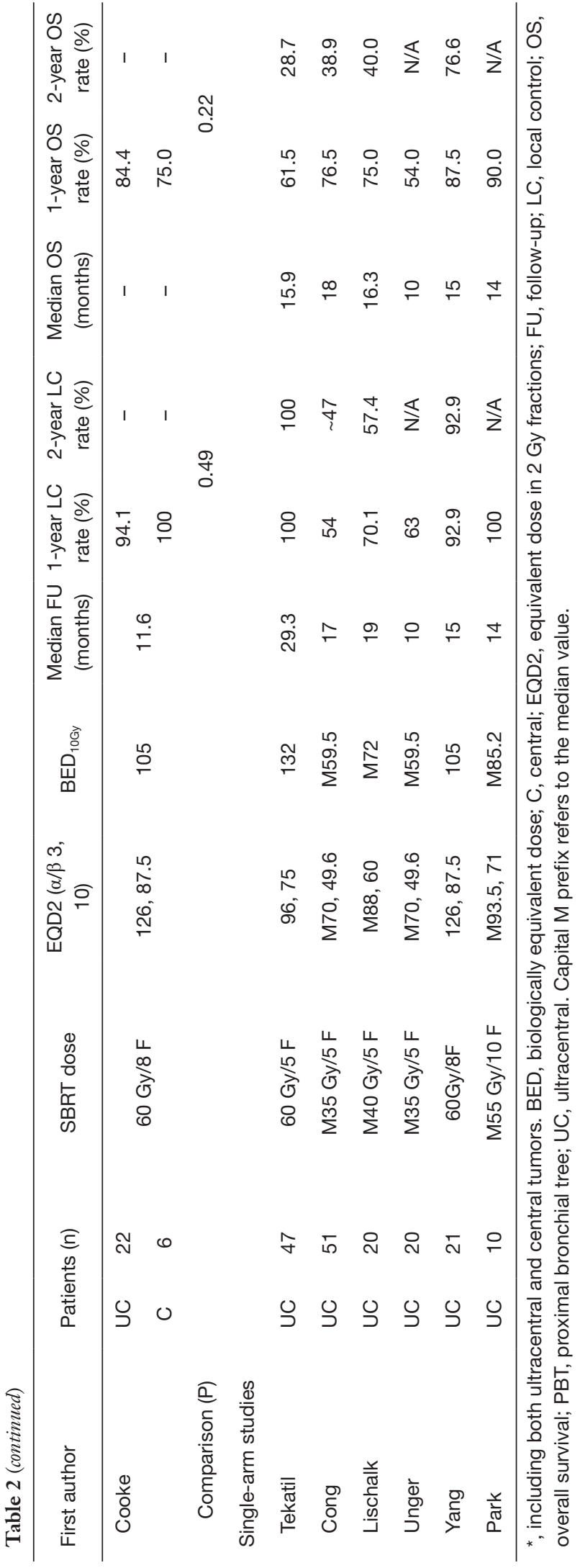

$(11,34)$. Therefore, the feasibility of SBRT, which can provide a curative opportunity, is of great clinical significance. The application of SBRT for UC tumors had been considered impossible until just a few years ago, and the feasibility of SBRT was gradually acknowledged by pioneering researchers (35). We previously performed a meta-analysis of the literature published until April 2018 (36). Surprisingly, our current study (merely 2 years later) included 3 times as many full-text publications as did the previous meta-analysis; this reflects the rigorous academic interest in the subject. In addition to the merits of including more research articles, the present study confers comparative results between UC and central tumor and dose-response for LC and suggestion of dose prescription of SBRT for UC tumors.

Regarding the primary outcomes of the study, the pooled $O S$ rates at 1 and 2 years were not different between the UC and central tumor groups. Although the 1-year LC rates for the UC and central tumor groups were significantly different $(93.9 \%$ vs. 97.8\%, $\mathrm{P}=0.023)$, the clinical impact of this difference might be moderate considering that the 2-year LC rates were not significantly different and the 1-year LC rates in both groups were very high. The narrow range of 1-year LC rates reported as well as the very low heterogeneity between the studies might also have produced the statistical difference. Taken together, oncologic outcomes after SBRT for UC and central tumors are thought to be very similar to outcomes in clinical practice.

In the pooled analyses of all UC tumor cohorts, the 1 -year LC and OS rates were favorable $(90.2 \%$ and $77.6 \%$, respectively), demonstrating the efficacy of SBRT. Subgroup comparisons revealed that a higher proportion of recurrence or metastasis influenced the LC rate $(\mathrm{P}=0.045)$, while the OS rate was largely affected by tumor size $(\mathrm{P}=0.003)$; these results were expected when considering current knowledge of tumor biology (37-39). The dose-response relationship for LC was significant in the meta-regression $(\mathrm{P}<0.0001$, Figure $2 A$ ). However, an overwhelming majority of studies used SBRT doses near or mildly higher from $100 \mathrm{~Gy}_{10}$, reflecting that most oncologists tended to prescribe higher doses than those recommended by Onishi et al. (40). and were concerned for possible toxicities simultaneously. The prescription dose of 59.5-72 $\mathrm{Gy}_{10}$ was shown to be suboptimal (27-29) as it only showed a pooled 1-year LC rate of $59.3 \%$. With the threshold of $85 \mathrm{~Gy}_{10}$, all studies with higher prescription doses reported a 1 -year LC rate of over $90 \%$, and the pooled rate was favorable at $94.3 \%$ 
Table 3 Comparison between ultracentral and central tumor groups

\begin{tabular}{|c|c|c|c|c|c|c|c|}
\hline Variable & $\begin{array}{c}\text { No of } \\
\text { cohorts }\end{array}$ & $\begin{array}{l}\text { Patients } \\
\text { (n) }\end{array}$ & $\begin{array}{l}\text { Heterogeneity } \\
\text { (P) }\end{array}$ & $\mathrm{I}^{2}(\%)$ & Heterogeneity & $\begin{array}{c}\text { Effect size } \\
(95 \% \mathrm{Cl})\end{array}$ & $\begin{array}{c}\text { Comparison } \\
\text { (P) }\end{array}$ \\
\hline \multicolumn{8}{|c|}{ Local control comparison (controlled studies only) } \\
\hline UC, 1-year & 7 & 224 & 0.961 & $\sim 0.0$ & Very low & $93.9 \%(95.6-98.9 \%)$ & 0.023 \\
\hline C, 1-year & 7 & 391 & 0.896 & $\sim 0.0$ & Very low & $97.8 \%(95.6-98.9 \%)$ & \\
\hline \multicolumn{8}{|c|}{ Overall survival comparison (controlled studies only) } \\
\hline UC, 1-year & 7 & 224 & 0.027 & 58.0 & High & $82.2 \%(71.1-89.7 \%)$ & 0.556 \\
\hline C, 1-year & 7 & 391 & 0.159 & 35.3 & Medium & $85.4 \%(78.9-90.1 \%)$ & \\
\hline Ultracentral & 8 & 247 & 0.196 & 29.1 & Medium & $9.0 \%(5.0-15.9 \%)$ & 0.06 \\
\hline Central & 8 & 500 & 0.532 & $\sim 0.0$ & Very low & $4.4 \%(2.8-6.9 \%)$ & \\
\hline \multicolumn{8}{|c|}{ Grade 5 complications (controlled studies only) } \\
\hline Ultracentral & 8 & 247 & 0.163 & 33.2 & Medium & $5.7 \%(2.6-11.9 \%)$ & 0.087 \\
\hline Central & 8 & 500 & 0.697 & $\sim 0.0$ & Very low & $2.3 \%(1.1-4.6 \%)$ & \\
\hline
\end{tabular}

C, central; UC, ultracentral.

with very low heterogeneity (Figure $2 \mathrm{~B}$ ). Therefore, we suggest the application of SBRT with a dose of at least $85 \mathrm{~Gy}_{10}$, which can be prescribed as either $55 \mathrm{~Gy}$ in 10 fractions (30) or 45 Gy in 5 fractions (12). Dose over $100 \mathrm{~Gy}_{10}$ can be prescribed with an expectation of a dose-response relationship; however, risk factors should be monitored as SBRT for UC tumors have a higher risk of complications than that for central tumors. Feasibility and additional efficacy regarding long-term LC of dose escalation should be evaluated in future studies.

The main reason UC tumors began to be treated independently of central tumors was that the former were thought to be more vulnerable to serious toxicities. Haseltine et al. (12). and Tekatli et al. (11), whose studies were performed relatively early, reported overwhelmingly high toxicity rates (grade $\geq 3$ complications rates in these studies were $24.8 \%$ and $38 \%$, respectively), thereby causing reluctance regarding the feasibility of SBRT. On the other hand, studies by Lenglet et al. (41), Raman et al. (13), and Chang et al. (15). found that the differences in serious toxicities between central and UC tumors were not significant. Given the inevitable full-dose irradiation to PBT when treating UC tumors, and results of higher grade $\geq 3$ complications rates ( $9 \%$ vs. $4.4 \%, \mathrm{P}=0.06$ ) and grade 5 complication $(5.7 \%$ vs. $2.3 \%, \mathrm{P}=0.087)$ with $\mathrm{UC}$ than with central tumors post-SBRT (with borderline significances), it seems that irradiating UC tumors produces a greater susceptibility to serious toxicities than does irradiating central tumors.

The pooled grade $\geq 3$ complication rate was $10.4 \%$, which was much lower than that revealed in the previous meta-analysis (23.2\%) (36). The pooled complication rates in previous meta-analyses were largely affected by those of Tekatli et al. (11). and Haseltine et al. (12), which reported relatively high rates of $24.8 \%$ and $38 \%$. However, in Tekatli et al.'s study (11), $60 \%$ of the tumors were $>5$ $\mathrm{cm}$ in diameter and $32 \%$ were $>7 \mathrm{~cm}$; these sizes were much larger than those of tumors commonly indicated for SBRT. In Haseltine et al.'s study (12), it was not clear that SBRT was the main cause of complications because some patients also received bevacizumab, exposure to which is a known risk factor for serious hemorrhage when treating 
A

Study name

$\begin{array}{ccc}\begin{array}{c}\text { Event } \\ \text { rate }\end{array} & \begin{array}{c}\text { Lower } \\ \text { limit }\end{array} & \begin{array}{c}\text { Upper } \\ \text { limit }\end{array} \\ 0.981 & 0.943 & 0.994 \\ 0.992 & 0.882 & 0.999 \\ 0.989 & 0.843 & 0.999 \\ 0.984 & 0.893 & 0.998 \\ 0.952 & 0.728 & 0.993 \\ 0.974 & 0.839 & 0.996 \\ 0.929 & 0.423 & 0.996 \\ 0.978 & 0.956 & 0.989 \\ 0.977 & 0.723 & 0.999 \\ 0.920 & 0.835 & 0.963 \\ 0.945 & 0.807 & 0.986 \\ 0.957 & 0.843 & 0.989 \\ 0.938 & 0.461 & 0.996 \\ 0.967 & 0.634 & 0.998 \\ 0.941 & 0.730 & 0.989 \\ 0.939 & 0.898 & 0.965\end{array}$

Pooled 1-year LC rate: $97.8 \%$ (95\% Cl: $95.6-98.9, \mathrm{C}$ group) vs. $93.9 \%$ (89.8-96.5, UC group) $\mathrm{P}=\mathbf{0 . 0 2 3}$
Event rate and $95 \% \mathrm{Cl}$

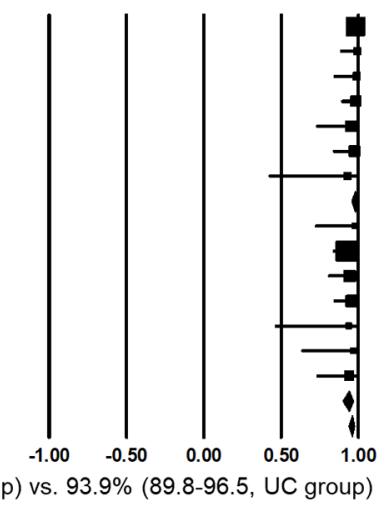
$\begin{array}{llll}\text { Lenglet_C } & 0.992 & 0.882 & 0.999\end{array}$ $\begin{array}{llll}\text { Meng_C } & 0.989 & 0.843 & 0.999\end{array}$ $\begin{array}{llll}\text { Chang C } & 0.984 & 0.893 & 0.998\end{array}$ Chauduhiru C $\quad 0.952 \quad 0.728 \quad 0.993$ $\begin{array}{llll}\text { Nguyen_C } & 0.974 & 0.839 & 0.996\end{array}$ $\begin{array}{llll}\text { Cooke_C } & 0.929 & 0.423 & 0.996 \\ & 0.978 & 0.956 & 0.989\end{array}$ Lenglet UC $\quad 0.920 \quad 0.835 \quad 0.963$ Meng UC $\quad 0.945 \quad 0.807 \quad 0.986$ Chauduhuri_UC Nguyen_UC $0.939 \quad 0.898 \quad 0.965$

C

Study name

$\begin{array}{lccc} & \begin{array}{c}\text { Event } \\ \text { rate }\end{array} & \begin{array}{c}\text { Lower } \\ \text { limit }\end{array} & \begin{array}{c}\text { Upper } \\ \text { limit }\end{array} \\ \text { Raman_C } & 0.807 & 0.739 & 0.861 \\ \text { Lenglet_C } & 0.900 & 0.795 & 0.954 \\ \text { Meng_C } & 0.989 & 0.843 & 0.999 \\ \text { Chang_C } & 0.836 & 0.721 & 0.909 \\ \text { Chauduhiru_C } & 0.977 & 0.723 & 0.999 \\ \text { Nguyen_C } & 0.846 & 0.697 & 0.929 \\ \text { Cooke_C } & 0.750 & 0.321 & 0.950 \\ & 0.854 & 0.789 & 0.901 \\ \text { Raman_UC } & 0.773 & 0.551 & 0.904 \\ \text { Lenglet_UC } & 0.870 & 0.775 & 0.929 \\ \text { Meng_UC } & 0.973 & 0.832 & 0.996 \\ \text { Chang_UC } & 0.652 & 0.505 & 0.775 \\ \text { Chauduhuri_UC } & 0.938 & 0.461 & 0.996 \\ \text { Nguyen_UC } & 0.760 & 0.482 & 0.915 \\ \text { Cooke_UC } & 0.844 & 0.631 & 0.945 \\ & 0.822 & 0.711 & 0.897\end{array}$

Pooled 1-year OS rate:

Event rate and $95 \% \mathrm{Cl}$

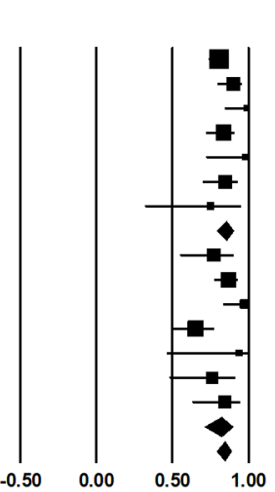
$\mathrm{P}=0.556$

E

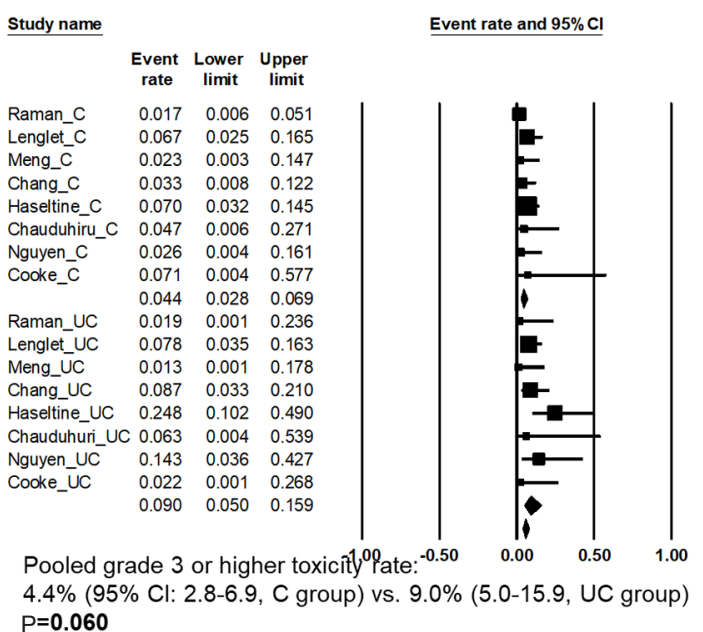

B

$\begin{array}{lllll}\text { Study name } & & & \\ & & \begin{array}{c}\text { Event } \\ \text { rate }\end{array} & \begin{array}{c}\text { Lower } \\ \text { limit }\end{array} & \begin{array}{c}\text { Upper } \\ \text { limit }\end{array} \\ \text { Raman_C } & 0.967 & 0.925 & 0.986 \\ \text { Lenglet_C } & 0.920 & 0.819 & 0.967 \\ \text { Meng_C } & 0.989 & 0.843 & 0.999 \\ \text { Chang_C } & 0.966 & 0.877 & 0.991 \\ \text { Chauduhiru_C } & 0.904 & 0.688 & 0.976 \\ \text { Nguyen_C } & 0.850 & 0.702 & 0.932 \\ & 0.937 & 0.883 & 0.967 \\ \text { Raman_UC } & 0.977 & 0.723 & 0.999 \\ \text { Lenglet_UC } & 0.730 & 0.620 & 0.817 \\ \text { Meng_UC } & 0.919 & 0.777 & 0.974 \\ \text { Chang_UC } & 0.957 & 0.843 & 0.989 \\ \text { Chauduhuri_UC } & 0.938 & 0.461 & 0.996 \\ \text { Nguyen_UC } & 0.890 & 0.603 & 0.977 \\ & 0.904 & 0.778 & 0.962\end{array}$

Event rate and $95 \% \mathrm{CI}$

Pooled 2-year LC rate: $93.7 \%$ (95\% Cl: $95.9-99.0$, C group) vs. $90.4 \%$ (89.5-96.6, UC group) $\mathrm{P}=0.459$

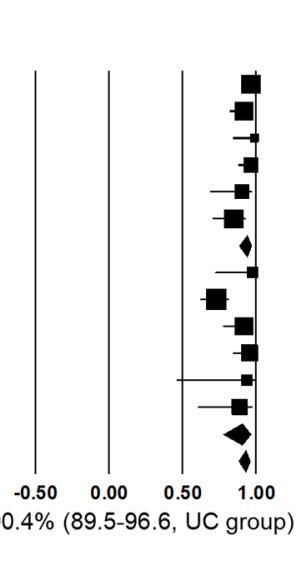

Event rate and $95 \% \mathrm{Cl}$

Study name

$\begin{array}{llll} & \begin{array}{c}\text { Event } \\ \text { rate }\end{array} & \begin{array}{c}\text { Lower } \\ \text { limit }\end{array} & \begin{array}{c}\text { Upper } \\ \text { limit }\end{array} \\ \text { Raman_C } & 0.627 & 0.550 & 0.698 \\ \text { Lenglet_C } & 0.833 & 0.717 & 0.908 \\ \text { Meng_C } & 0.892 & 0.759 & 0.956 \\ \text { Chang_C } & 0.577 & 0.451 & 0.694 \\ \text { Chauduhiru_C } & 0.632 & 0.414 & 0.807 \\ \text { Nguyen_C } & 0.730 & 0.571 & 0.846 \\ & 0.719 & 0.610 & 0.808 \\ \text { Raman_UC } & 0.455 & 0.261 & 0.663 \\ \text { Lenglet_UC } & 0.623 & 0.510 & 0.724 \\ \text { Meng_UC } & 0.892 & 0.745 & 0.959 \\ \text { Chang_UC } & 0.504 & 0.363 & 0.644 \\ \text { Chauduhuri_UC } & 0.800 & 0.386 & 0.962 \\ \text { Nguyen_UC } & 0.760 & 0.482 & 0.915 \\ & 0.664 & 0.514 & 0.787\end{array}$

Pooled 2-year OS rate:

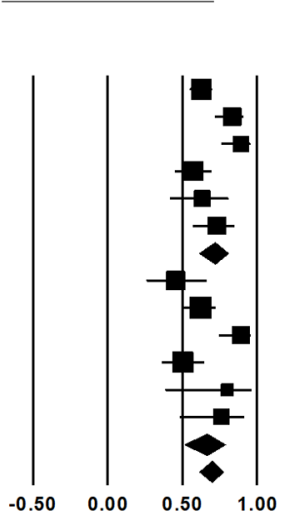

$71.9 \%$ (95\% Cl: $61.0-80.8, \mathrm{C}$ group) vs. $66.4 \%$ (51.4-78,7, UC group) $\mathrm{P}=0.522$

F
Event rate and $95 \% \mathrm{Cl}$

Event Lower Upper rate limit limit Total Raman_C $\quad 0.003 \quad 0.000 \quad 0.043 \quad 0 / 180$ $\begin{array}{lllll}\text { Lenglet_C } & 0.033 & 0.008 & 0.123 & 2 / 60\end{array}$ $\begin{array}{lllll}\text { Meng_C } & 0.023 & 0.003 & 0.147 & 1 / 43\end{array}$ $\begin{array}{lllll}\text { Chang_C } & 0.033 & 0.008 & 0.122 & 2 / 61\end{array}$ $\begin{array}{lllll}\text { Haseltine C } & 0.005 & 0.000 & 0.082 & 0 / 90\end{array}$ $\begin{array}{lllllll}\text { Chauduhiru C } & 0.023 & 0.001 & 0.277 & 0 / 21\end{array}$ $\begin{array}{lllll}\text { Nguyen_C } & 0.013 & 0.001 & 0.171 & 0 / 39\end{array}$ $\begin{array}{lllll}\text { Cooke_c } & 0.071 & 0.004 & 0.577 & 0 / 6\end{array}$ Raman UC $\quad \begin{array}{lllll}0.023 & 0.011 & 0.046 & 5 / 500\end{array}$ Lenglet_UC $\quad 0.052 \quad 0.020 \quad 0.130 \quad 4 / 77$ $\begin{array}{lllll}\text { Meng_UC } & 0.013 & 0.001 & 0.178 & 0 / 37\end{array}$ $\begin{array}{llllll}\text { Chang UC } & 0.022 & 0.003 & 0.139 & 1 / 46\end{array}$ Hastine_UC $0.222 \quad 0.0060 .464 \quad 4 / 18$ ChaudunuriUC $0.063 \quad 0.004 \quad 0.539 \quad 0 / 7$ NguyenUC $0.0720 .0100 .371 \quad 1 / 14$ $\begin{array}{lllll}\text { Cooke_UC } & 0.022 & 0.001 & 0.268 & 0 / 22\end{array}$

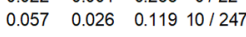

Pooled grade 5 toxicity rate: $2.3 \%$ ( $95 \% \mathrm{Cl}: 1.1-4.6, \mathrm{C}$ group) vs. $5.7 \%$ (2.6-11.9, UC group) $\mathrm{P}=\mathbf{0 . 0 8 7}$

Figure 1 Forest plots for the pooled analyses of controlled studies (comparison between the ultracentral and central tumor groups). (A) 1-year local control rate; (B) 2-year local control rate; (C) 1-year overall survival rate; (D) 2-year overall survival rate; (E) Grade $\geq 3$ complication rate; (F) Grade 5 complication rate. 
Table 4 Pooled analyses of all the ultracentral tumor cohorts

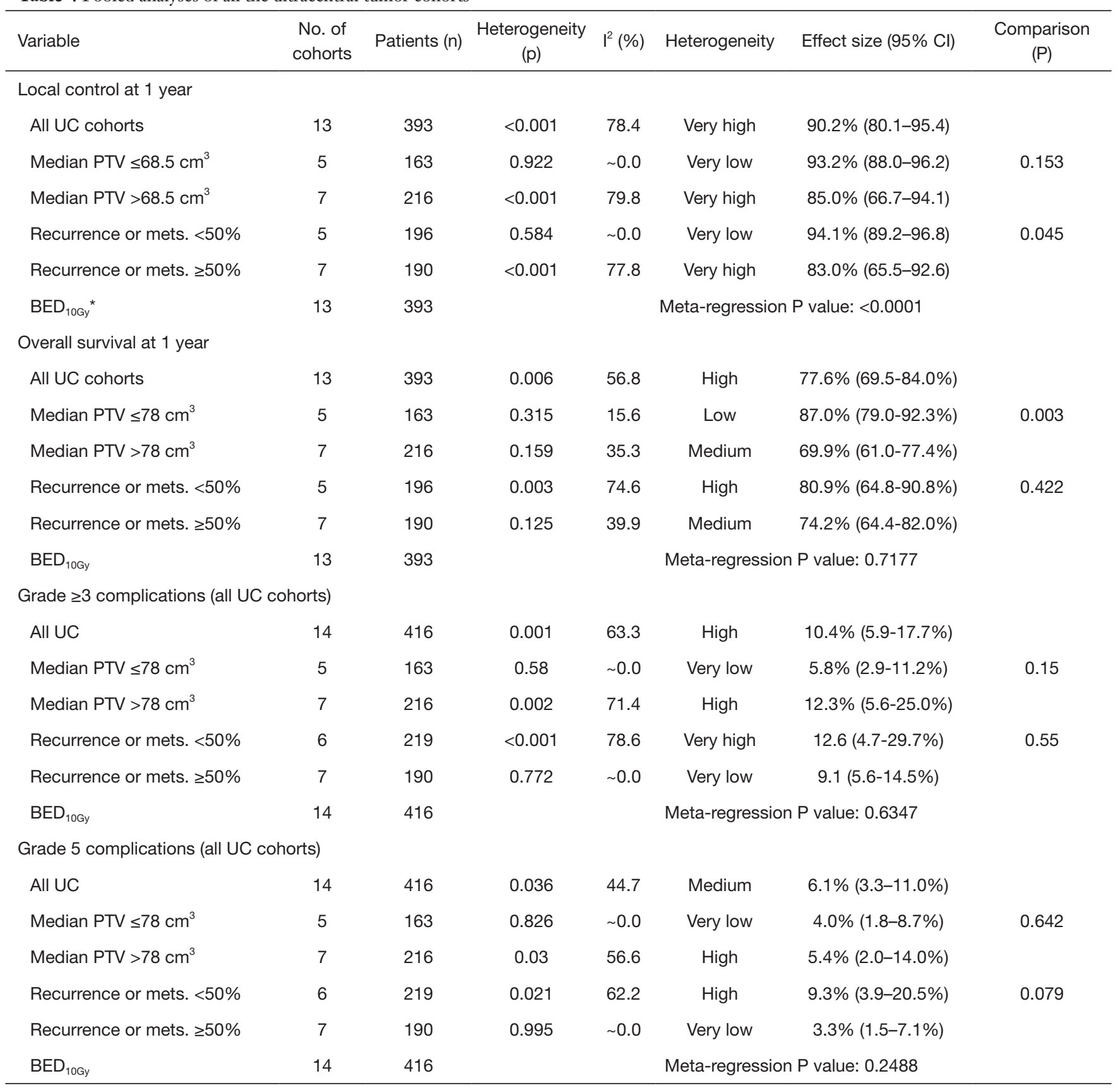

*, median dose, or prescribed dose for the majority of patients. BED, biologically equivalent dose; Cl, confidence interval; mets, metastases; PTV, planning target volume; UC, ultracentral.

central lung cancer (42). In fact, the authors also suggested that bevacizumab might have contributed to hemorrhagic complications, and also noted that gram-negative bacterial pneumonia (another serious complication that arose) is generally not caused by non-invasive treatments such as
SBRT. Contrarily, more recent trials including those by Lenglet et al. (14), Meng et al. (17), Raman et al. (13), and Chang et al. (15). which might avoid such risks previously suggested, found much more acceptable rates of toxicity ( $0 \%$ to $~ 8 \%$ ) although all patients in these studies were 

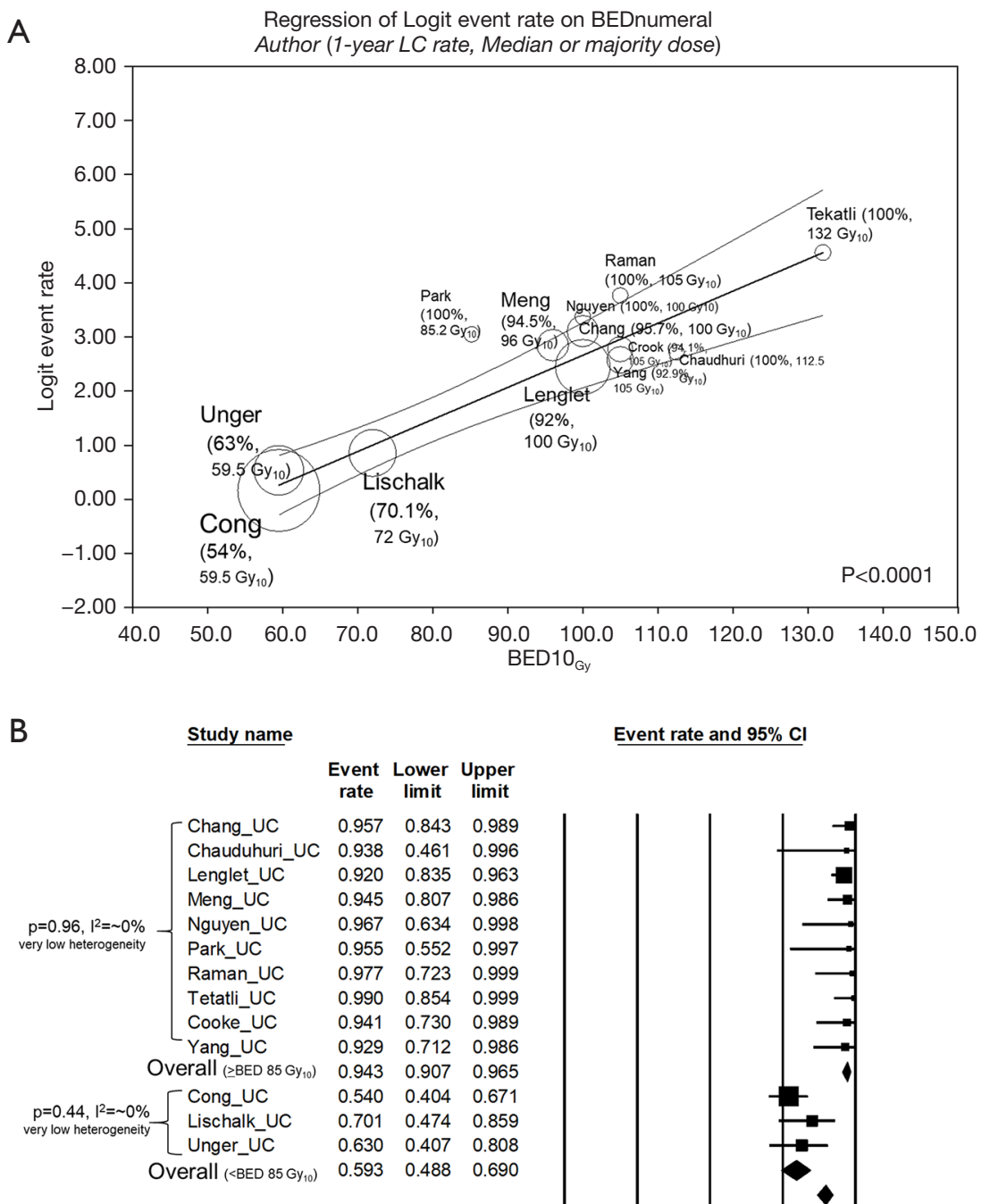

Subgroup comparison: $\mathrm{P}<0.001$

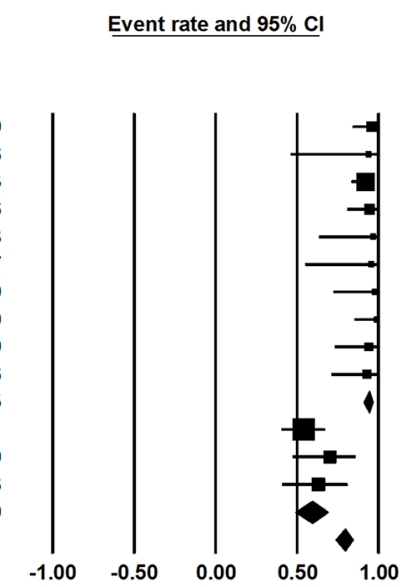

Figure 2 Dose-response relationship for local control in the scatterplot. (A) Meta-regression scatterplot for BED ${ }_{10 \mathrm{~Gy}}$ and 1 -year local control; (B) Forest plot of subgroup pooled analysis for 1-year local control with threshold of $85 \mathrm{~Gy}_{10}$.

prescribed more than $100 \mathrm{~Gy}_{10}$.

Grade 5 complication is the most significant factor determining the application of SBRT for UC tumors reluctant. Of note, most researchers reported factors that may have significantly influenced fatal toxicity. Tekatli et al. (11). reported 10 patients among 47 with UC tumors who experienced fatal toxicity, including 7 with hemorrhages. Anticoagulant use, squamous histology, excessive irradiation dose $\left(\mathrm{D}_{\operatorname{Max}}>123 \%\right)$, and endobronchial involvement were the presumed causes of such toxicities. Haseltine et al. (12). reported fatal toxicities in 4 of their 18 patients with UC tumors $(22.5 \%)$ and claimed that bevacizumab exposure might have caused fatal hemorrhagic toxicities. Studies by Chang et al. (15), Meng et al. (17), Lenglet et al. (14), and Unger et al. (29). revealed much lower fatal toxicity rates $(2-5 \%)$ than did the previous 2 studies, suggesting that underlying lung diseases such as interstitial lung disease and idiopathic pulmonary fibrosis might have been associated with fatal respiratory toxicities. Although none of the individual studies reported statistically significant differences in serious toxicities between patients with UC and central tumors $(9,12,13,15,41)$, considering the small patient number of individual studies and borderline significance found in our subgroup comparisons, we support the notion that applying SBRT for UC tumors carries a greater risk of fatal toxicities than does applying 


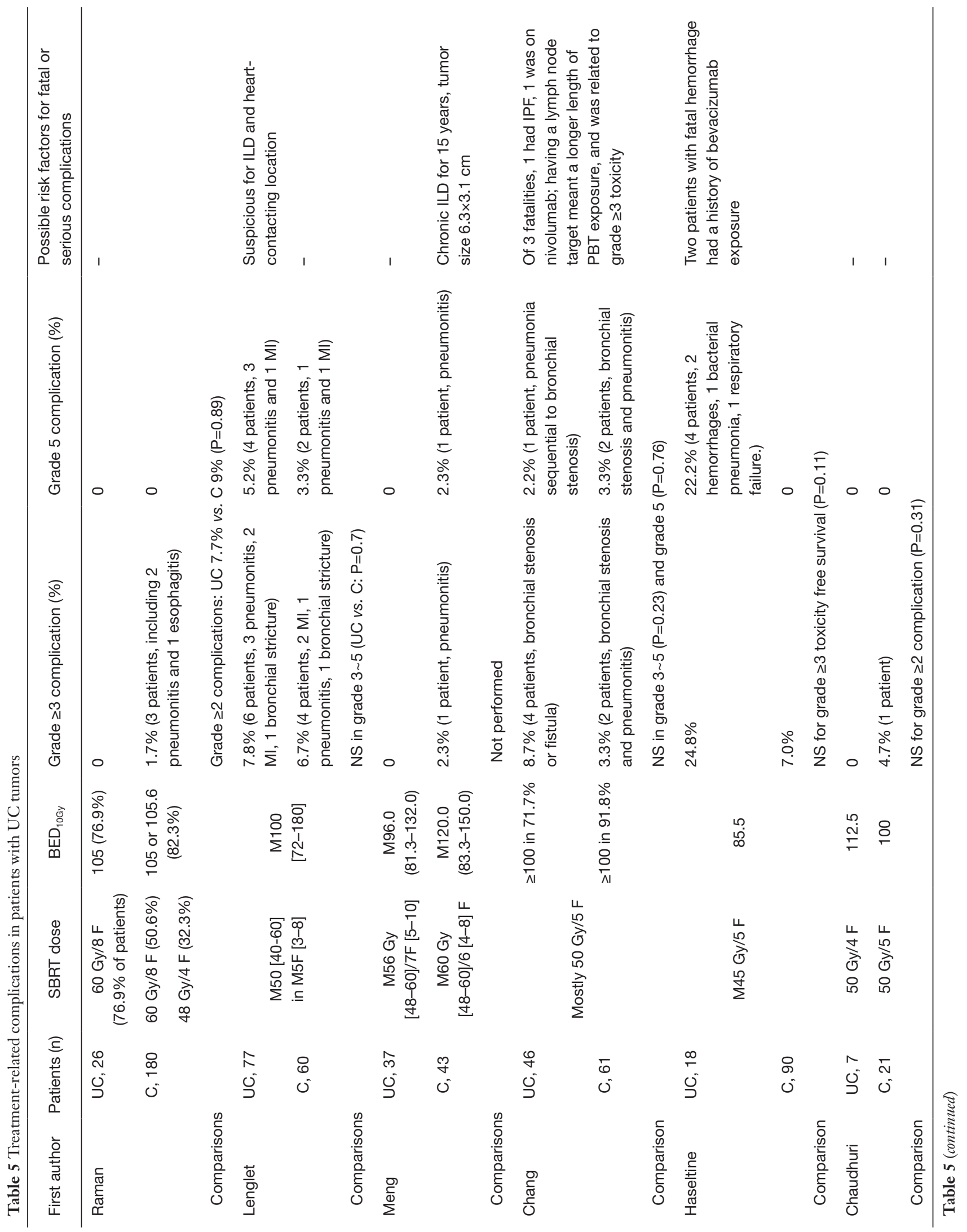




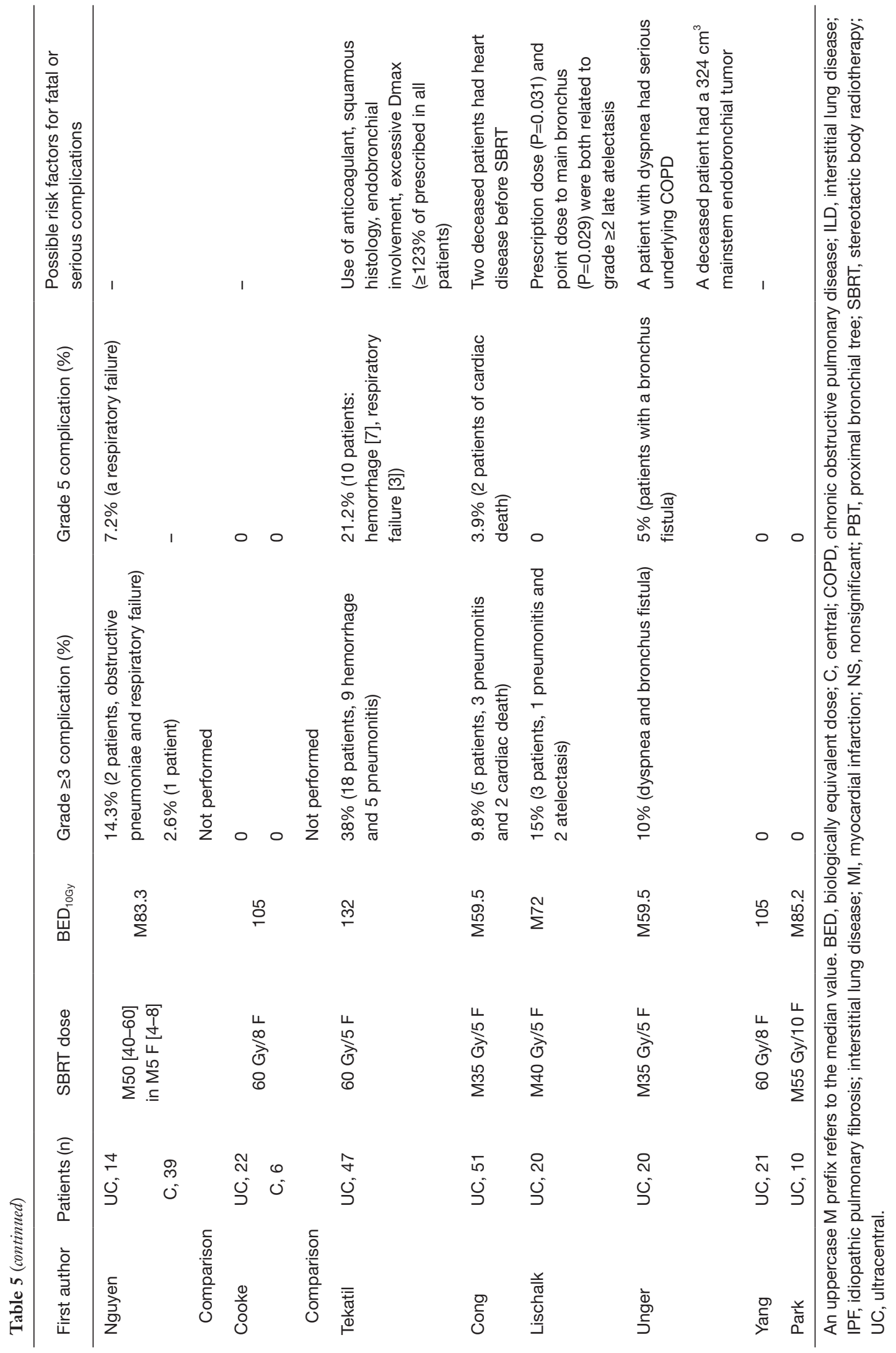


it for central tumors. Hence, all risk factors suggested by previous investigators should be taken into consideration before treatment.

Limitations of the present meta-analysis include the non-randomized and retrospective design, and the clinical heterogeneity of the patients. Meta-analyses of observational studies are controversial because innate heterogeneity among studies might affect the pooled estimates (43). SBRT for UC tumors was contraindicated until recently when the indication was updated following pioneering research. As UC tumors are commonly inoperable or else require extensive surgeries, assessment of other curative modalities such as SBRT is crucial. In such situations, meta-analyses of observational studies can be one of the few options that provide helpful information for clinical practice (43). Short follow-up periods are another limitation in recent studies; we did not perform pooled analyses of the 2-year outcome rates in all UC cohorts because the available data were limited and follow-up periods in UC case series were too short. It should be considered that reporting of late toxicity events depends on follow-up and that risks of fatal toxicities may be higher. The heterogeneity of definitions for UC tumors is another drawback that ought to be resolved. The assessment of the feasibility or efficacy of treatment for UC tumors might be difficult if the definition of the target disease is unclear. We suggest that future studies use agreeable definitions and terminology regarding UC tumors.

\section{Conclusions}

The oncologic outcomes of SBRT for patients with UC and central tumors were comparable, although patients treated for UC tumors are more prone to serious toxicities. Nevertheless, SBRT for UC tumors is feasible considering the moderate rate of toxicities and the clinical need for a non-invasive curative modality. Considering the dose-response relationship, a dose of at least $85 \mathrm{~Gy}_{10}$ is recommended to be prescribed, and doses near or moderately higher than $100 \mathrm{~Gy}_{10}$ can be considered with cautious monitoring for risk factors of complications. Studies with longer follow-up which enable assessments of higher dose for sustained LC are warranted. The identified causes of fatal toxicities should be avoided in clinical practice as much as possible.

\section{Acknowledgments}

Funding: This study is supported by National research fund of Korea (NRF-2018R1D1A1B07046998). The research grant supported only methodological aspects including statistical analysis and linguistic correction, and did not affect major contents including the results and conclusions.

\section{Footnote}

Reporting Checklist: The authors have completed the PRISMA reporting checklist. Available at http://dx. doi. org/10. 21037/tlcr-20-503

Conflicts of Interest: All authors have completed the ICMJE uniform disclosure form (available at http://dx. doi. org/10.21037/tlcr-20-503). The authors have no conflicts of interest to declare.

Ethical Statement: The authors are accountable for all aspects of the work in ensuring that questions related to the accuracy or integrity of any part of the work are appropriately investigated and resolved.

Open Access Statement: This is an Open Access article distributed in accordance with the Creative Commons Attribution-NonCommercial-NoDerivs 4.0 International License (CC BY-NC-ND 4.0), which permits the noncommercial replication and distribution of the article with the strict proviso that no changes or edits are made and the original work is properly cited (including links to both the formal publication through the relevant DOI and the license). See: https://creativecommons.org/licenses/by-nc-nd/4.0/.

\section{References}

1. Bray F, Ferlay J, Soerjomataram I, et al. Global cancer statistics 2018: GLOBOCAN estimates of incidence and mortality worldwide for 36 cancers in 185 countries. CA Cancer J Clin 2018;68:394-424.

2. National Cancer Comprehensive Network (NCCN). Principles of radiation therapy (NSCL-C), Non-small cell lung cancer. NCCN guidelines version 4.2019. Available online: https://www.nccn.org/professionals/physician_gls/ $\mathrm{pdf} / \mathrm{nscl} . \mathrm{pdf}$

3. Callister ME, Baldwin DR, Akram AR, et al. British Thoracic Society guidelines for the investigation and management of pulmonary nodules. Thorax 2015;70 Suppl 2:ii1-54.

4. Chang JY, Senan S, Paul MA, et al. Stereotactic ablative radiotherapy versus lobectomy for operable stage I non- 
small-cell lung cancer: a pooled analysis of two randomised trials. Lancet Oncol 2015;16:630-7.

5. Hiley C, Salem A, Batchelor T, et al. Great debate: surgery versus stereotactic radiotherapy for early-stage non-small cell lung cancer. Thorax 2020;75:198-9.

6. Timmerman R, McGarry R, Yiannoutsos C, et al. Excessive toxicity when treating central tumors in a phase II study of stereotactic body radiation therapy for medically inoperable early-stage lung cancer. J Clin Oncol 2006;24:4833-9.

7. Senthi S, Haasbeek CJ, Slotman BJ, et al. Outcomes of stereotactic ablative radiotherapy for central lung tumours: a systematic review. Radiother Oncol 2013;106:276-82.

8. Yu T, Shin I, Yoon WS, et al. Stereotactic body radiotherapy for centrally located primary non-small cell lung cancer: a meta-analysis. Clin Lung Cancer 2019;20:e452-62.

9. Chaudhuri AA, Tang C, Binkley MS, et al. Stereotactic ablative radiotherapy (SABR) for treatment of central and ultra-central lung tumors. Lung Cancer 2015;89:50-6.

10. Corradetti MN, Haas AR, Rengan R. Central-airway necrosis after stereotactic body-radiation therapy. N Engl J Med 2012;366:2327-9.

11. Tekatli H, Haasbeek N, Dahele M, et al. Outcomes of hypofractionated high-dose radiotherapy in poor-risk patients with "ultracentral" non-small cell lung cancer. J Thorac Oncol 2016;11:1081-9.

12. Haseltine JM, Rimner A, Gelblum DY, et al. Fatal complications after stereotactic body radiation therapy for central lung tumors abutting the proximal bronchial tree. Pract Radiat Oncol 2016;6:e27-33.

13. Raman S, Yau V, Pineda S, et al. Ultracentral Tumors Treated With Stereotactic Body Radiotherapy: SingleInstitution Experience. Clin Lung Cancer 2018;19:e803-10.

14. Lenglet A, Campeau MP, Mathieu D, et al. Risk-adapted stereotactic ablative radiotherapy for central and ultracentral lung tumours. Radiother Oncol 2019;134:178-84.

15. Chang JH, Poon I, Erler D, et al. The safety and effectiveness of stereotactic body radiotherapy for central versus ultracentral lung tumors. Radiother Oncol 2018;129:277-83.

16. Nguyen KNB, Hause DJ, Novak J, et al. Tumor control and toxicity after SBRT for ultracentral, central, and paramediastinal lung tumors. Pract Radiat Oncol 2019;9:e196-202.

17. Meng MB, Wang HH, Zaorsky NG, et al. Risk-adapted stereotactic body radiation therapy for central and ultracentral early-stage inoperable non-small cell lung cancer.
Cancer Sci 2019;110:3553.

18. Hall EJ, Giaccia AJ. Radiobiology for the Radiologist. Philadelphia: Lippincott Williams \& Wilkins, 2006.

19. Peterson J, Welch V, Losos M, et al. The NewcastleOttawa scale (NOS) for assessing the quality of nonrandomised studies in meta-analyses. Ottawa: Ottawa Hospital Research Institute; 2011.

20. Borenstein M, Hedges LV, Higgins JP, et al. Introduction to meta-analysis. Hoboken: John Wiley \& Sons, 2011.

21. DerSimonian R, Kacker R. Random-effects model for meta-analysis of clinical trials: an update. Contemp Clin Trials 2007;28:105-14.

22. Cochran WG. The combination of estimates from different experiments. Biometrics 1954;10:101-29.

23. Higgins JP, Thompson SG. Quantifying heterogeneity in a meta-analysis. Stat Med 2002;21:1539-58.

24. Egger M, Davey Smith G, Schneider M, et al. Bias in meta-analysis detected by a simple, graphical test. BMJ 1997;315:629-34.

25. Rosenthal R. Combining results of independent studies. Psychological Bulletin 1978;85:185-93.

26. Duval S, Tweedie R. Trim and fill: A simple funnel-plotbased method of testing and adjusting for publication bias in meta-analysis. Biometrics 2000;56:455-63.

27. Cong Y, Sun B, Wang J, et al. Outcomes and toxicity of stereotactic body radiation therapy for advanced stage ultra-central non-small cell lung cancer. Thorac Cancer 2019;10:1567-75.

28. Lischalk JW, Malik RM, Collins SP, et al. Stereotactic body radiotherapy (SBRT) for high-risk central pulmonary metastases. Radiat Oncol 2016;11:28.

29. Unger K, Ju A, Oermann E, et al. CyberKnife for hilar lung tumors: report of clinical response and toxicity. J Hematol Oncol 2010;3:39.

30. Park S, Kim Y, Yoon WS, et al. A preliminary experience of moderate-intensity stereotactic body radiation therapy for ultra-central lung tumor. Int J Radiat Biol 2019;95:1287-94.

31. Cooke R, Camilleri P, Chu KY, et al. Stereotactic body radiotherapy for moderately central and ultra-central oligometastatic disease: Initial outcomes. Tech Innov Patient Support Radiat Oncol 2020;13:24-30.

32. Yang D, Cui J, Zhao J, et al. Stereotactic ablative radiotherapy of $60 \mathrm{~Gy}$ in eight fractions is safe for ultracentral non-small cell lung cancer. Thorac Cancer 2020;11:754-61.

33. Stereotactic body radiotherapy for centrally located lung tumor. Annual conference of Korean Lung Cancer 
Association; 2019, Seoul, Korea.

34. Gómez-Caro A, Garcia S, Reguart N, et al. Determining the appropriate sleeve lobectomy versus pneumonectomy ratio in central non-small cell lung cancer patients: an audit of an aggressive policy of pneumonectomy avoidance. Eur J Cardiothorac Surg 2011;39:352-9.

35. Chen H, Laba JM, Zayed S, et al. Safety and effectiveness of stereotactic ablative radiotherapy for ultra-central lung lesions: a systematic review. J Thorac Oncol 2019;14:1332-42.

36. $\operatorname{Rim} \mathrm{CH}, \mathrm{Kim} \mathrm{Y}, \mathrm{Kim} \mathrm{CY}$, et al. Is stereotactic body radiotherapy for ultra-central lung tumor a feasible option? A systemic review and meta-analysis. Int J Radiat Biol 2019;95:329-37.

37. Milano MT, Kong FM, Movsas B. Stereotactic body radiotherapy as salvage treatment for recurrence of nonsmall cell lung cancer after prior surgery or radiotherapy. Transl Lung Cancer Res 2019;8:78-87.

38. Dunlap NE, Larner JM, Read PW, et al. Size matters: a comparison of T1 and T2 peripheral non-small-cell lung cancers treated with stereotactic body radiation therapy

Cite this article as: Rim CH, Shin IS, Yoon WS, Park S. Dose-response relationship of stereotactic body radiotherapy for ultracentral tumor and comparison of efficacy with central tumor: a meta-analysis. Transl Lung Cancer Res 2020;9(4):1268-1284. doi: 10.21037/tlcr-20-503
(SBRT). J Thorac Cardiovasc Surg 2010;140:583-9.

39. Kim E, Song C, Kim MY, et al. Long-term outcomes after salvage radiotherapy for postoperative locoregionally recurrent non-small-cell lung cancer. Radiat Oncol J 2017;35:55-64.

40. Onishi H, Shirato H, Nagata Y, et al. Hypofractionated stereotactic radiotherapy (HypoFXSRT) for stage I nonsmall cell lung cancer: updated results of 257 patients in a Japanese multi-institutional study. J Thorac Oncol 2007;2:S94-100.

41. Lenglet A, Mathieu D, Campeau MP, et al. Risk-Adapted Lung SBRT for Central and Ultra-Central Tumors. Int J Radiat Oncol Biol Phys 2017;99:E473-4.

42. Goto K, Endo M, Kusumoto M, et al. Bevacizumab for non-small-cell lung cancer: A nested case control study of risk factors for hemoptysis. Cancer Sci 2016;107:1837-42.

43. Stroup DF, Berlin JA, Morton SC, et al. Meta-analysis of observational studies in epidemiology: a proposal for reporting. Meta-analysis Of Observational Studies in Epidemiology (MOOSE) group. JAMA 2000;283:2008-12. 


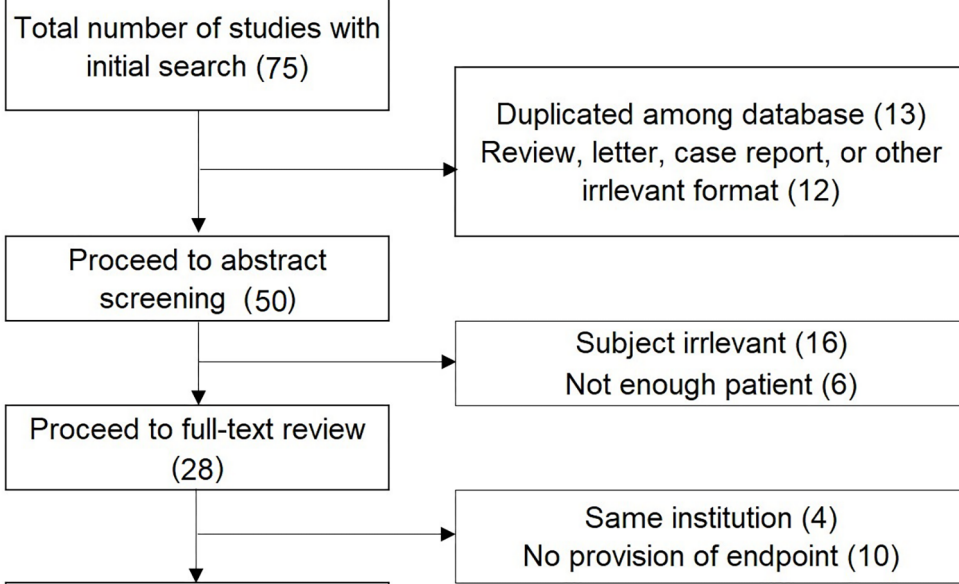

14 studies are finally included

Figure S1 Study inclusion plot. 


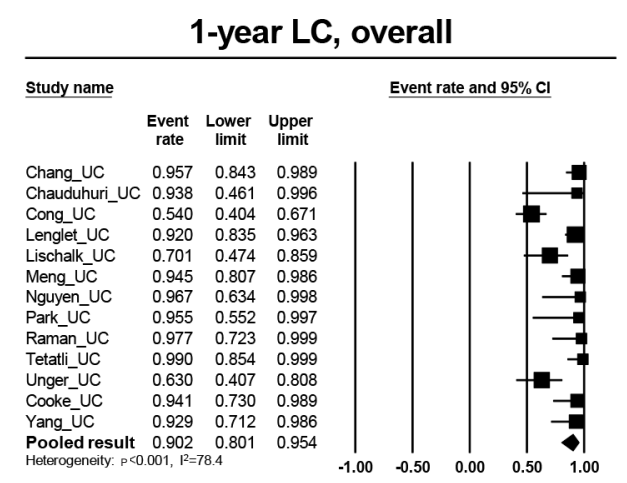

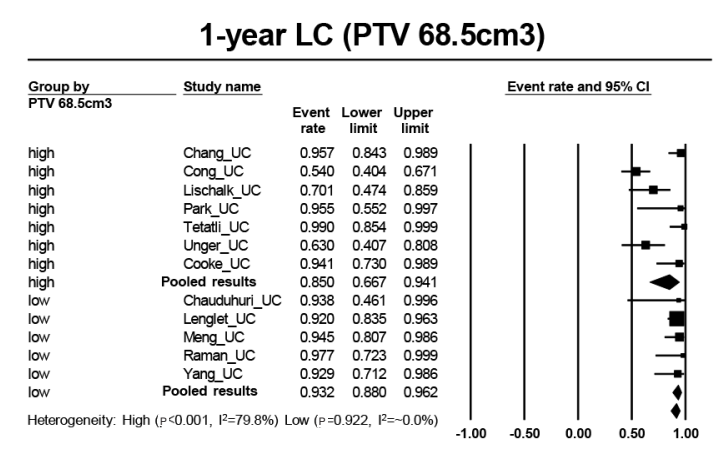

1-year LC (mets, recur 50\%)
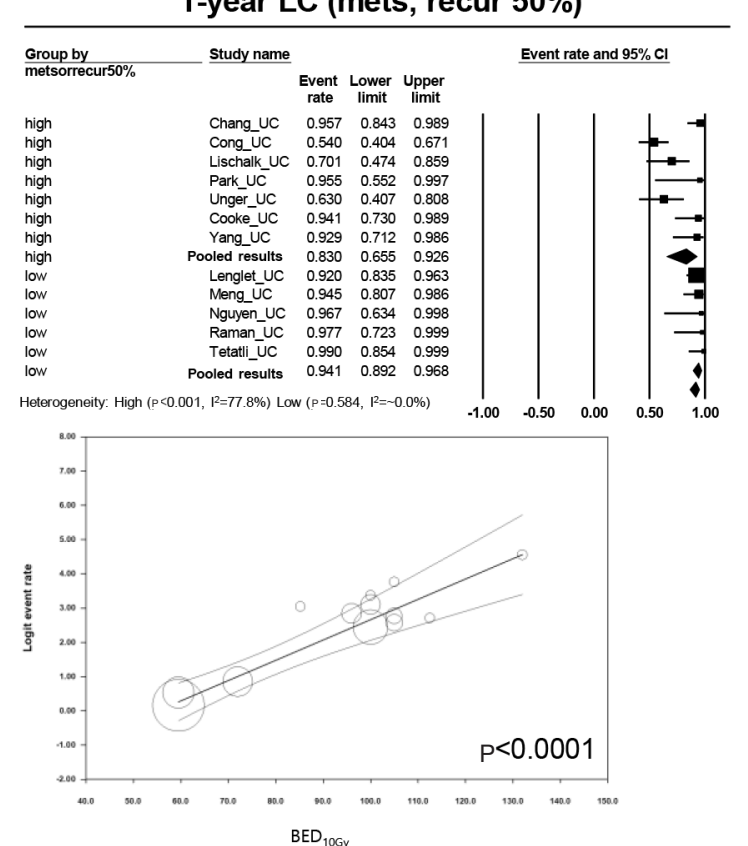

B

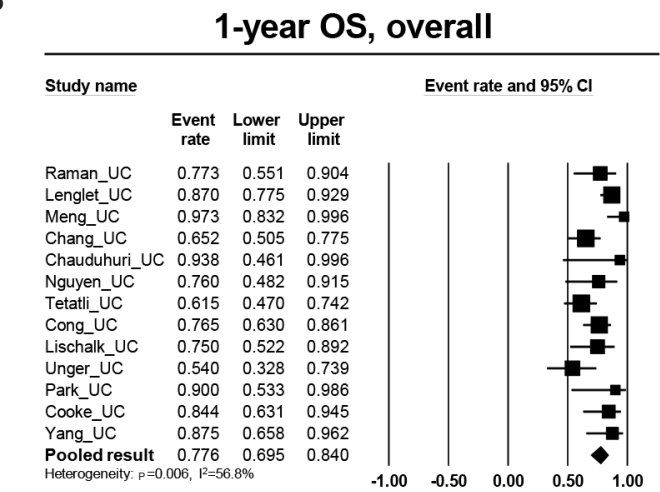

1-year OS (PTV 68.5cm3)

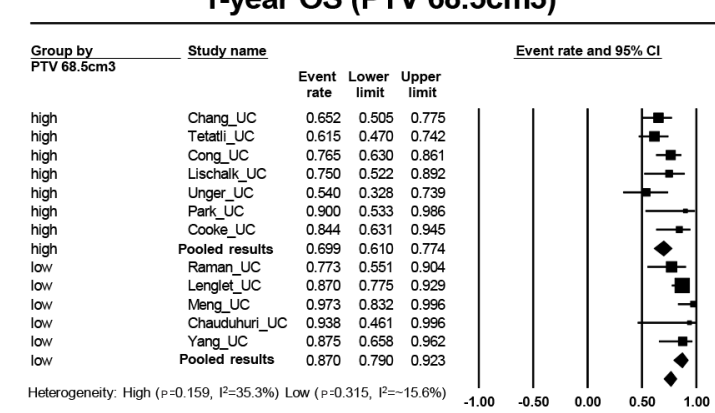

1-year OS (mets, recur 50\%)
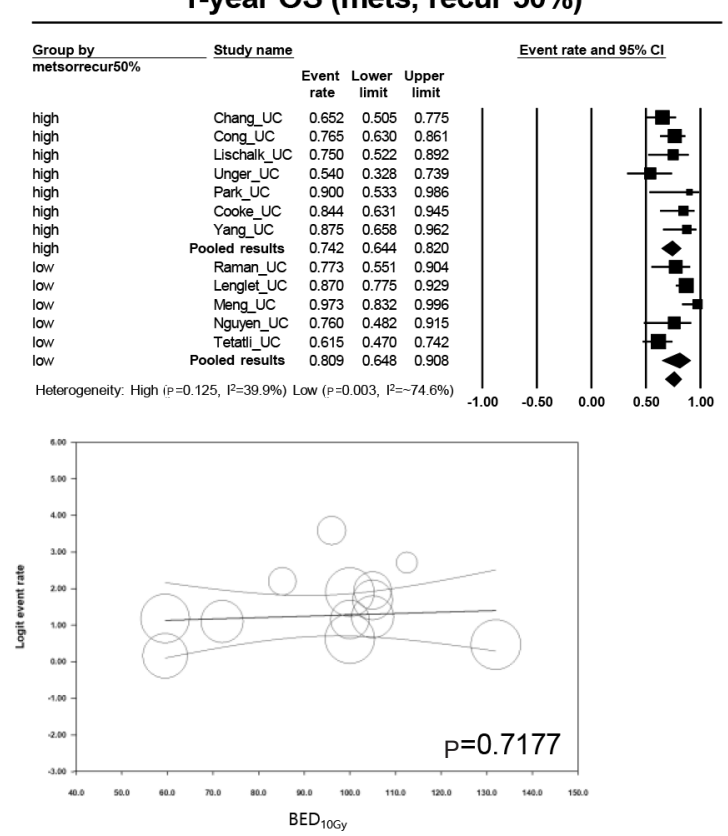

C

Grade $>=3$ complication, overall study name Event rate and $95 \% \mathrm{Cl}$

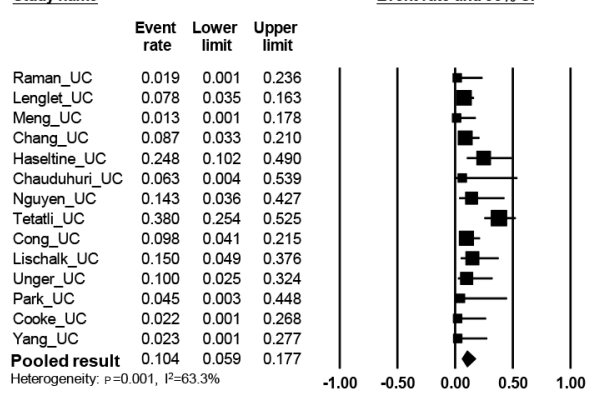

Grade $>=3$ complication (PTV $68.5 \mathrm{~cm} 3$ )

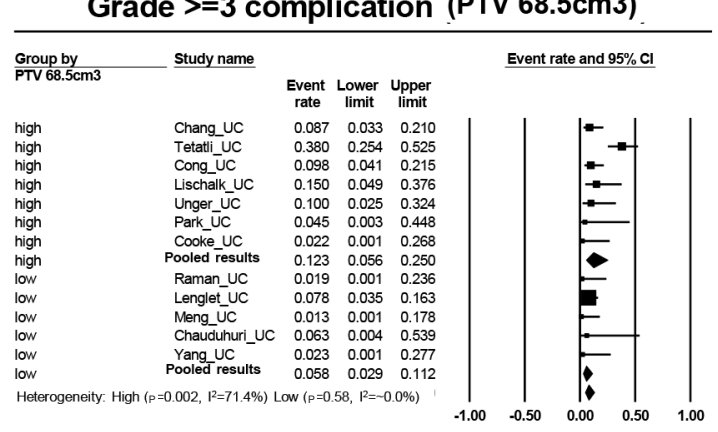

Grade $>=3$ complication (mets, recur $50 \%$ )
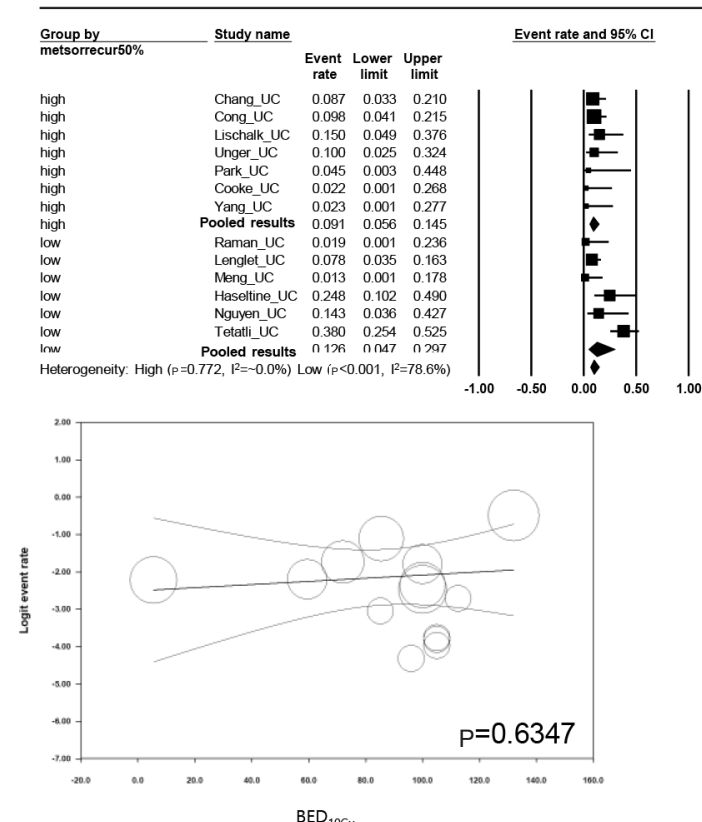

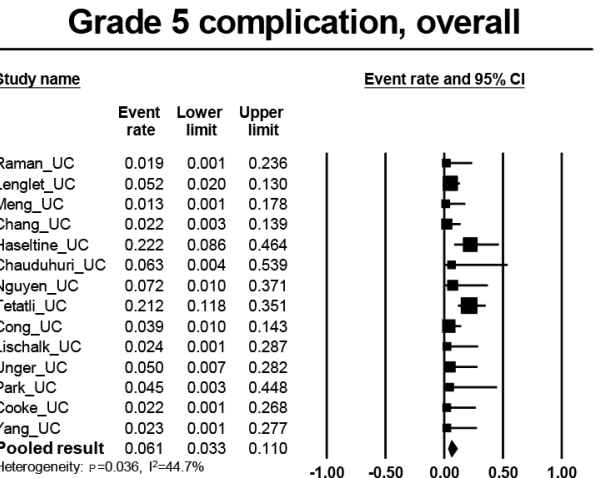

Grade 5 com

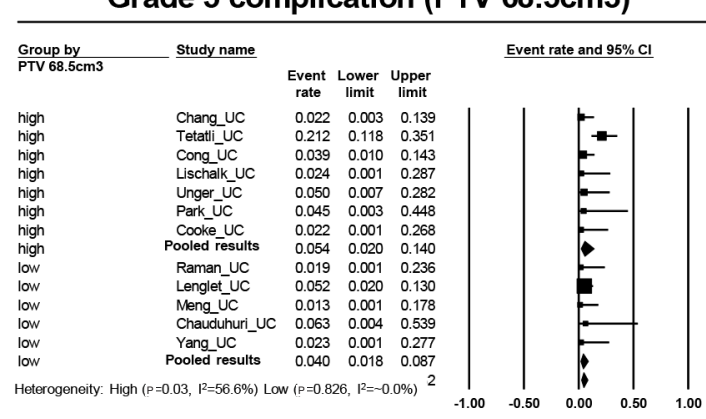

Grade 5 complication (mets, recur $50 \%$ )
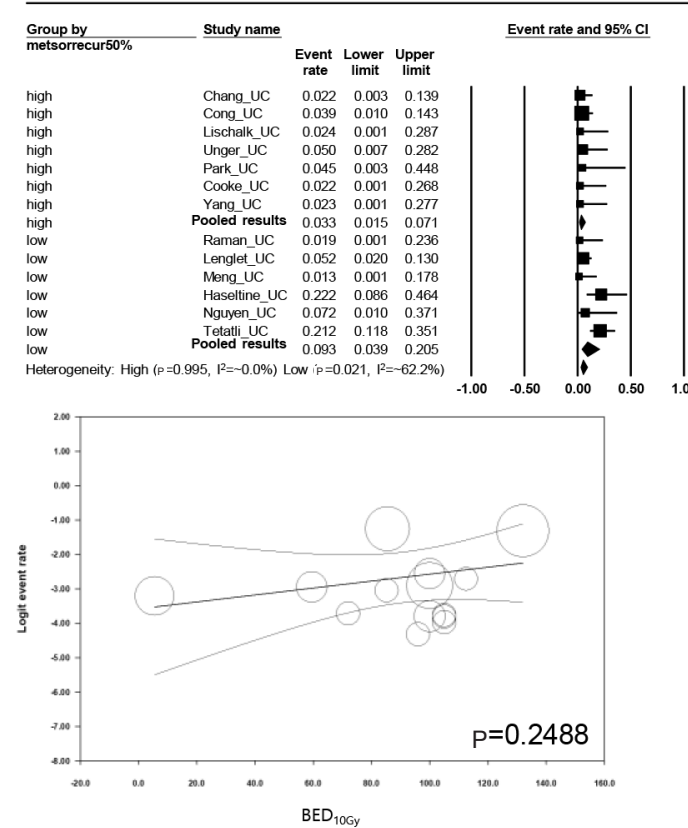

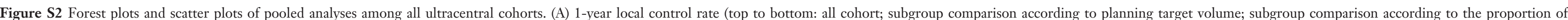

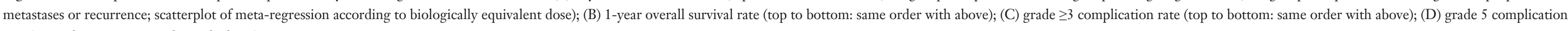
rate (top to bottom: same order with above). 